\title{
Resenha
}

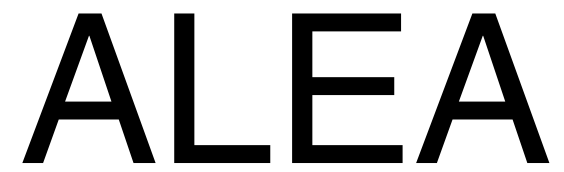




\section{Livro, de José Luís Peixoto. Lisboa: Quetzal, 2010. 263 PP.}

Livro, o sexto romance de José Luís Peixoto (1974), tem como contexto a emigração portuguesa para França e a literatura enquanto universo complexo, enigmático e contraditório. Estes dois temas surgem ligados na primeira frase do romance, mas o leitor não poderá compreender a verdadeira amplitude desta associação senão na segunda parte do livro.

"A mãe pousou o livro nas mãos do filho" (11) inicia uma narrativa que seduz o leitor pela imprevisibilidade e pelo dramatismo das situações, pela densidade psicológica das personagens e pelo encadeamento dos episódios, que se vão sucedendo numa progressão cronológica assinalada, entre parênteses, no início de alguns capítulos ou no seu interior, imediatamente antes do parágrafo que se segue e no mesmo tipo de letra do texto. Há ainda palavras-chave, como "(Fonte)" (26) ou "Posto da guarda" (101), números, o nome de uma personagem e, por vezes, a representação pictórica de uma mala, que também delimitam os momentos narrativos. À medida que o romance avança, o andamento dos episódios e a alternância entre eles intensificam-se.

Também neste aspecto da sintagmática narrativa o autor recorre, no nível gráfico, a uma estratégia que visa marcar esses momentos: um espaço em branco, equivalente a duas ou três linhas, entre cada parte. Num livro que tem tanto de romance tradicional como de narrativa pós-moderna, esta técnica, tal como as que enumeramos acima, contribui para a inscrição do romance numa categoria genealógica singular. As personagens deste romance estão divididas entre Portugal, de onde algumas nunca saíram, como Josué e a velha Lubélia, e França, para onde partiram na situação de emigrantes não propriamente convencionais e de onde voltam para períodos de férias e, mais tarde, no caso de Adelaide e do filho "Livro", definitivamente.

Lubélia, personagem amargurada por ter abortado e por ter sido afastada pelos pais da experiência amorosa, envia a sobrinha à força para França, para separá-la de Ilídio, que, ao aperceber-se disso, decide partir à procura de Adelaide. Para além do episódio inicial, constituído pelo abandono de Ilídio pela mãe, que parte para França, é este o núcleo a partir do qual se desencadeiam todas as outras linhas efabulativas do romance. Apesar de narrados auto- 
nomamente, todos estes episódios se encontram associados numa lógica de alternância cinematográfica que dá ao leitor a possibilidade de saber o que as personagens não sabem umas das outras.

Fala-se, neste romance, de vidas humanas individuais, dos seus desejos, vontades, erros e conflitos; fala-se de amor, de morte, de encontros e desencontros; e fala-se também de Portugal como povo, com as suas crendices e obsessões, vícios e virtudes, alegrias e tragédias, e como país que vive a tragédia de uma ditadura e a conquista de liberdade política, social e individual. 1974 é, por isso mesmo, um ano privilegiado neste livro, em especial os dias que precedem e sucedem à revolução do 25 de Abril. "27 de Abril de 1974” é uma data com implicações narrativas e autobiográficas: é a data que assinala o fim da primeira parte do romance, narrado em terceira pessoa, e a data de nascimento do narrador (autodiegético) da segunda parte, que é também a data de nascimento do autor empírico (cuja projeção autobiográfica tem ainda a ver com o facto de os pais de José Luís Peixoto terem sido emigrantes em França nos anos 60).

O livro que Ilídio recebe da mãe é o mesmo livro que ele, adolescente, oferecerá a Adelaide, com quem, muito mais tarde, terá um filho ilegítimo, cujo nome insólito é também o nome deste romance: Livro.

Este é um romance que muda radicalmente de registo no início da segunda parte, que surpreende o leitor com um inquérito, constituído por doze perguntas, enunciado nestes termos: "Indique os seguintes dados" (207). Percebe-se, mais à frente, que o próprio narrador autodiegético responderá a este questionário repentino $\mathrm{e}$ insólito, em que entram aspectos de natureza não só civil e biográfica, mas também pessoal: "Nome da sua mãe" ou "Nome do seu bilhete de identidade", por um lado, e "Adjectivo que melhor caracteriza o penteado que tem neste momento" ou "Número de vezes que lava os dentes por semana" (207), por outro. Antes, contudo, dos primeiros indícios que fazem a ligação com a intriga da primeira parte do romance, surge outro momento perturbador que acentua ainda mais o estranhamento causado pelo inquérito: "Preencha os espaços em branco com as respostas anteriores" (209).

Esta segunda parte não se desliga completamente da anterior, mas obriga o leitor a rever as expectativas que foi criando ao longo de duzentas páginas. Paralelamente às sequências de ações, às relações entre personagens e à caracterização direta e indireta de espaços 
e figuras, as incursões no metaliterário inscrevem este romance no âmbito pós-moderno. O leitor lê o livro, primeiro na segurança de uma história bem-construída e escrita com a elegância de um autor que sabe usar o ritmo, a metáfora e a comparação: "Cada martelada que acertava na parede era como uma explosão no centro da terra. [...] As cabeças dos martelos eram pesadelos de aço maciço, trovôes negros. O Ilídio segurava o seu martelo com as duas mãos e acertava na parede, que caía em grandes postas caiadas, com tijolos vermelhos nas pontas, como entranhas" (178).

Mas este Livro também interpela o leitor através da visão criativa do pós-moderno, que já não se satisfaz com a apresentação de uma história linear e previsível; interessa-lhe, dialogando ironicamente com o passado histórico, literário e cultural, inovar pelo lado da reflexão metaliterária. Para o narrador deste Livro, que no final se dirige a um narratário, tudo está em julgamento e em movimento: a sociedade, o pensamento e a própria literatura: "Este livro podia acabar aqui. Ficávamos assim, no vácuo desta revelação. The end. Ou talvez nem seja sequer uma revelação, talvez seja apenas um sinal da minha incapacidade de interpretar detalhes" (261).

Carlos Nogueira

Universidade Nova de Lisboa

carlosnogueira1@sapo.pt 